\title{
Tetrastichus howardi (Hymenoptera: Eulophidae): first report of parasitism in Oxydia vesulia (Lepidoptera: Geometridae)
}

\author{
Ana Laura Favoreto ${ }^{a *}$ (D), Rafaela Freitas Pavani ${ }^{a}$ (D), Murilo Fonseca Ribeiro ${ }^{a}$ (D), \\ Antonio José Vinha Zanuncio ${ }^{b}$ (D), Marcus Alvarenga Soares ${ }^{c}$ (D), José Cola Zanuncio ${ }^{d}$ (D) \\ and Carlos Frederico Wilcken ${ }^{a}$

\begin{abstract}
aDepartamento de Proteção Vegetal, Faculdade de Ciências Agronômicas, Universidade Estadual Paulista - UNESP, Av. Universitária, 3780, CEP 18610-034, Botucatu, SP, Brasil

${ }^{b}$ Departamento de Engenharia Florestal, Universidade Federal de Viçosa - UFV, CEP 36570-900, Viçosa, MG, Brasil
\end{abstract} \\ 'Programa de Pós-graduação em Produção Vegetal, Universidade Federal dos Vales Jequitinhonha e Mucuri - UFVJM, \\ CEP 39100-000, Diamantina, MG, Brasil \\ ${ }^{\text {d} D e p a r t a m e n t o ~ d e ~ E n t o m o l o g i a, ~ I n s t i t u t o ~ d e ~ B i o t e c n o l o g i a ~ A p l i c a d o ~ a ̀ ~ A g r o p e c u a ́ r i a ~-~ B I O A G R O, ~ U n i v e r s i d a d e ~ F e d e r a l ~}$ \\ de Viçosa - UFV, CEP 36570-900, Viçosa, MG, Brasil \\ *e-mail: analaurafavoreto@gmail.com
}

Received: September 12, 2019 - Accepted: January 21, 2020 - Distributed: May 31, 2021

(With 2 figures)

\begin{abstract}
The adaptation of native lepidopteran species to eucalyptus plantations reduces the productivity of this crop in Brazil. Oxydia vesulia Cramer (Lepidoptera: Geometridae) is a secondary pest, frequently reported in eucalyptus plantations with population outbreaks and economic damages. Methods of biological control of this pest may include the use of the exotic pupae endoparasitoid Tetrastichus howardi Olliff (Hymenoptera: Eulophidae), reported as efficient to controlling lepidopteran pests. The parasitism of $O$. vesulia caterpillars and pupae by $T$. howardi was evaluated under controlled conditions $\left(25 \pm 1{ }^{\circ} \mathrm{C}, 60 \pm 20 \%\right.$ humidity and $\left.12: 12 \mathrm{~h} \mathrm{~L}: \mathrm{D}\right)$. Each $O$. vesulia caterpillar or pupae was individually placed in a flat-bottom tube with 10 and 15 females of $T$. howardi for $48 \mathrm{~h}$, respectively. The parasitoids were removed after that period, the caterpillars were fed and the pupae were maintained until emergence of the parasitoid or formation of pupae and emergence of adults of this pest. The fourth-instar caterpillars of $O$. vesulia, after the parasitism period, were kept in pots with Eucalyptus urophylla leaves, changed daily until the end of the experiment. A total of $40 \%$ of the caterpillars died before the pre-pupae stage, $40 \%$ reached the pupae stage and died due to inadequate adult formation and $20 \%$ generated moths, but none adult parasitoid emerged from the caterpillars. All pupae of $O$. vesulia were parasitized and showed emergence of parasitoids. The parasitism of $O$. vesulia caterpillars and pupae by T. howardi shows the potential of this natural enemy for the integrated management of this defoliator pest in eucalyptus plantations.
\end{abstract}

Keywords: biological control, caterpillar and pupae parasitoid, Eucalyptus.

\section{Tetrastichus howardi (Hymenoptera: Eulophidae): primeiro relato de parasitismo em Oxydia vesulia (Lepidoptera: Geometridae)}

\section{Resumo}

A adaptação de espécies nativas de lepidópteros a plantios de eucalipto reduz a produtividade dessa cultura no Brasil. Oxydia vesulia Cramer (Lepidoptera: Geometridae) é praga-secundária, frequentemente, relatada em plantios de eucalipto com surtos populacionais e danos econômicos. Métodos de controle biológico, dessa praga, podem incluir o uso do endoparasitoide exótico de pupas Tetrastichus howardi Olliff (Hymenoptera: Eulophidae) relatado como eficiente para o controle de lepidópteros-pragas. O parasitismo de lagartas e pupas de $O$. vesulia por $T$. howardi foi avaliado em condições controladas $\left(25 \pm 1^{\circ} \mathrm{C}, 60 \pm 20 \%\right.$ umidade e $12 \mathrm{~h}$ fotoperíodo). Cada lagarta ou pupa de $O$. vesulia foi colocada individualmente em tubos de fundo chato com 10 e 15 fêmeas de $T$. howardi por $48 \mathrm{~h}$, respectivamente e, após esse período, os parasitoides foram removidos, as lagartas alimentadas e as pupas mantidas até a emergência do parasitoide ou formação de pupas ou de adultos dessa praga. As lagartas de quarto ínstar de $O$. vesulia, após o período de parasitismo, foram mantidas em potes com folhas de Eucalyptus urophylla trocadas, diariamente, até o fim do experimento. Um total de $40 \%$ das lagartas de $O$. vesulia morreu antes da fase de pré-pupa, $40 \%$ atingiram o estágio de pupa e morreram devido à má formação ou problemas e $20 \%$ originaram mariposas, porém nenhum parasitoide 
adulto emergiu das lagartas. Todas as pupas de $O$. vesulia foram parasitadas e tiveram emergência de parasitoides. O parasitismo de lagartas e pupas de $O$. vesulia por $T$. howardi mostra o potencial desse inimigo natural para o manejo integrado desse desfolhador em cultivos de eucalipto.

Palavras-chave: controle biológico, parasitoide de pupas e de lagartas, Eucalyptus.

\section{Introduction}

Oxydia vesulia Cramer (Lepidoptera: Geometridae) is a native moth observed in population outbreaks, damaging eucalyptus plantations in Brazil (Campos and Cure, 1993; Santos et al., 2002; Oliveira et al., 2003; Zanuncio et al., 2018). This insect has six or seven instars lasting around 27 days for males and 31 for females, and the leaf consumption by its caterpillars increase considerably from the fourth instar (Zanuncio et al., 1993; Espindola and Gonçalves, 2000). Oxydia vesulia female moths live an average of 12 days and can lay 1,970 eggs in up to nine postures (Espíndola and Gonçalves, 2000). This specie is considered a secondary pest and its populations tend to increase with the period of cultivation of eucalyptus in the same area (Zanuncio et al., 2018).

Biological control, including bioinsecticides based on the entomopathogenic bacterium Bacillus thuringiensis Berliner and releases of parasitoids and predators, should be preferred in the management of lepidopteran pests in eucalyptus plantations (Zanuncio et al., 1992; Barbosa et al., 2016).

Tetrastichus howardi Olliff (Hymenoptera: Eulophidae) is an exotic pupae endoparasitoid with primary or hyperparasitoid behavior associated with lepidopteran pests and have been used to effectively control many lepidopteran species in important crops (Baitha et al., 2004; La Salle; Polaszek, 2007). The first report of this parasitoid in Brazil was in Diatraea saccharalis Fabricius (Lepidoptera: Crambidae) pupae obtained from corn plants (Cruz et al., 2011) and D. saccharalis pupae from sugar cane (Vargas et al., 2011). This natural enemy has parasitized caterpillars and pupae of $D$. saccharalis (Pereira et al., 2015) and species of the families Crambidae, Noctuidae, Plutellidae and Sphyngidae (Moore and Kfir, 1995; Cruz et al., 2011; Vargas et al., 2011; Barbosa et al., 2015), but it has not been reported for the Geometridae family, which contains some of major eucalyptus primary pests (Zanuncio et al., 1994).

The objective was to evaluate $T$. howardi parasitism on $O$. vesulia caterpillars and pupae.

\section{Material and Methods}

The experiments were conducted at the Laboratory of Biological Control of Forest Pests (LCBPF) of the São Paulo State University (UNESP), School of Agriculture, in Botucatu, São Paulo state, Brazil. The caterpillars of $O$. vesulia were collected on field during an outbreak in Minas Gerais State in 2018 and transported to São Paulo State University where they were identified. The rearing of $O$. vesulia caterpillars were kept in cages in a room with a controlled environment $\left(25 \pm 1{ }^{\circ} \mathrm{C}, 60 \pm 20 \%\right.$ humidity and 12:12 h L:D), with Eucalyptus urophylla leaves changed daily, up to the pupae stage of this insect. The procedure for rearing $T$. howardi were to keep them in sealed glass tubes, fed with pure honey and multiplied in D. saccharalis pupae up to 48 hours old. The parasitized pupae were transferred to 2 -liter plastic pots after a period of exposure of 72 hours, which were maintained under a controlled-environment room $\left(25 \pm 1{ }^{\circ} \mathrm{C}, 60 \pm 20 \%\right.$ humidity and 12:12 h L:D).

Ten fourth-instar caterpillars of $O$. vesulia were maintained per 1-liter plastic pot, receiving daily Eucalyptus urophylla leaves. The parasitism was allowed for 48 hours with 100 individuals of $T$. howardi ( $24 \mathrm{~h}$ old) per plastic pot in the proportion of 10 parasitoid females $/ O$. vesulia caterpillar. Pupae of $O$. vesulia (weight between $482-773 \mathrm{mg}$ ) at $48 \mathrm{~h}$ of age were individualized in flat-bottom tubes $(8.5 \mathrm{~cm}$ long $\times 2.5 \mathrm{~cm}$ in diameter) with $15 \mathrm{~T}$. howardi females (48 h old and fed with honey drops) sealed with "voil" fabric. After this period, the parasitoids were removed and the $O$. vesulia caterpillars and pupae remained under the same controlled conditions. The caterpillar keep eating E. urophylla leaves and compared with control caterpillars to observe their behavior. The emergence of the progeny, length cycle (egg-adult), number of parasitoids emerged per $O$. vesulia caterpillar or pupae (progeny) and the sex ratio of $T$. howardi were evaluated.

\section{Results}

Tetrastichus howardi parasitized and killed 40\% of the $O$. vesulia caterpillars, but none adult parasitoid emerged from them. It parasitized $100 \%$ of the O. vesulia pupae, emerged from and killed $100 \%$ of the pupae of this Lepidoptera (Figure 1). It is life cycle (egg-adult) was $16.4 \pm 0.25$ days. The progeny of $T$. howardi was $321 \pm 28.7$ parasitoids/pupa of $O$. vesulia with a sex ratio of $0.807 \pm 0.022$.

The color, body consistency and behavior varied, and the consumption of eucalypt leaves was lower for the $O$. vesulia caterpillars which were parasitized by $T$. howardi females, while the control caterpillars kept feeding until the pupae stage. A total of $40 \%$ of caterpillars died before the pre-pupa stage, $40 \%$ reached the pupa stage and died due to inadequate adult formation and $20 \%$ generated moths (Figure 2).

The emergence of $T$. howardi from $100 \%$ of the $O$. vesulia pupae demonstrates that this host is adequate for the development of this parasitoid.

The results report for the first time in controlled conditions the capacity of $T$. howardi to parasitize pupae of $O$. vesulia. 


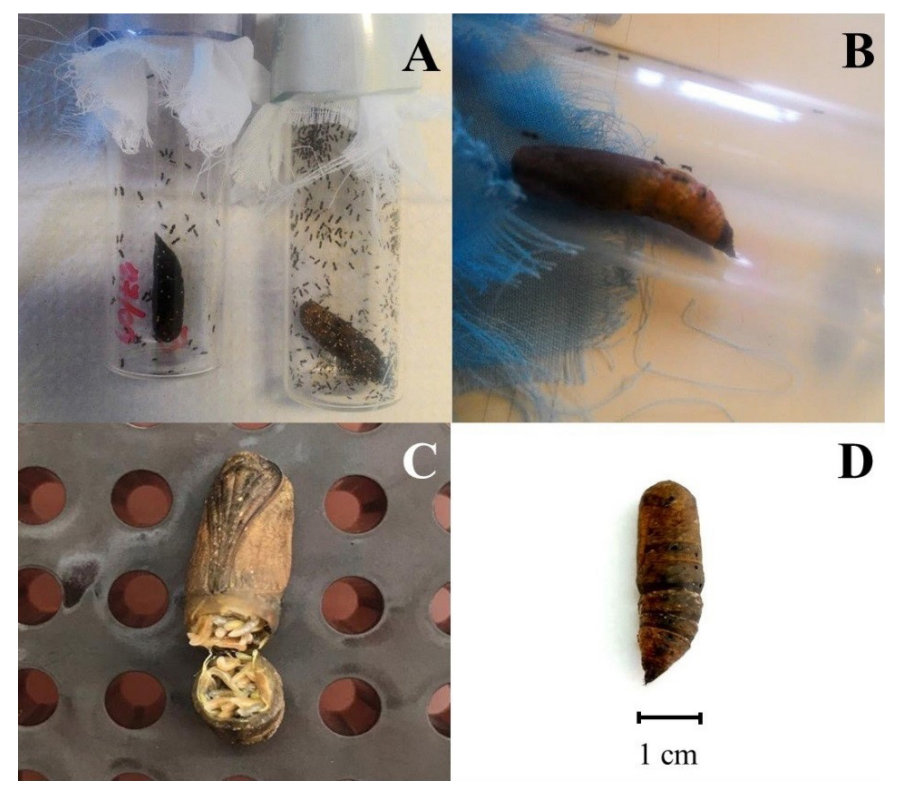

Figure 1. Adults of Tetrastichus howardi (Hymenoptera: Eulophidae) emerged from the Oxydia vesulia (Lepidoptera: Geometridae) pupae (A), Tetrastichus howardi females parasitizing Oxydia vesulia pupae (B), larvae of Tetrastichus howardi in development (C) and Oxydia vesulia pupae after the parasitoid emergence (D).

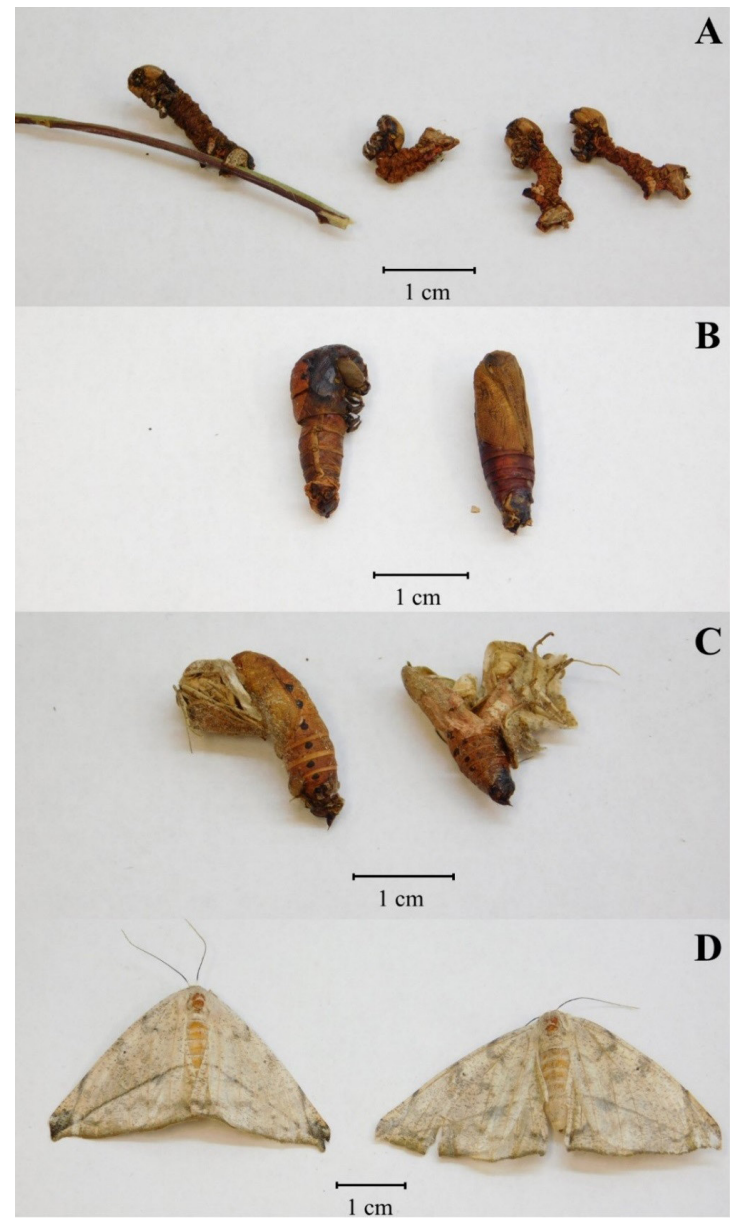

Figure 2. Oxydia vesulia (Lepidoptera: Geometridae) caterpillars that did not reach the pupae stage (A), malformation of pupae and adults (B and C) and adults that survived the Tetrastichus howardi (Hymenoptera: Eulophidae) parasitism (D). 


\section{Discussion}

A parasitism rate of $40 \%$ by $T$. howardi in O. vesulia larvae and the $2 \%$ of parasitism by $T$. howardi in $D$. saccharalis larvae suggest that this life stage may poses a stronger immune response against this parasitoid (Pereira et al., 2015).

Changes in the color and consistency of the $O$. vesulia caterpillar body and the reduction of consumption of E. urophylla leaves after parasitism by $T$. howardi might be due to fluids injected during oviposition by this parasitoid, suppressing the host immune system (Asgari and Rivers 2011; Colinet et al. 2013) and causing its death. Oxydia vesulia adults, originated from caterpillars of this insect submitted to $T$. howardi, indicate that they may have been favored by frequent feeding, increasing the immune response against parasitism.

The emergence of parasitoids from all O. vesulia pupae represents the first report of this activity on laboratory, and thus includes another host species for T. howardi, suppressing the cellular defense of this Lepidoptera and consuming its nutritional resources for the development of its progeny, as reported for Palmistichus elaeisis Delvare and LaSalle and T. diatraeae (Hymenoptera: Eulophidae) in the host Anticarsia gemmatalis Hübner (Lepidoptera: Noctuidae) (Andrade et al., 2010).

The egg-adult cycle of $T$. howardi in pupae of $O$. vesulia was shorter when compared to $D$. saccharalis, around 20 days less (Pereira et al., 2015), which may be associated with nutritional availability, size, immune response or pupae stage period of the host (Favero et al., 2013, Ribeiro et al., 2019).

The progeny of $T$. howardi in $O$. vesulia pupae was lower than that of this parasitoid in Erinnyis ello Linnaeus (Lepidoptera: Sphyngidae) pupae. However, O. vesulia is an adequate host for T. howardi, because the pupae of this host, with medium weight of $522.9 \mathrm{mg}$, generated $321 \pm 28.7$ parasitoids (one parasitoid offspring produced per $1.63 \mathrm{mg}$ of host pupa), while the mean weight of E. ello pupae was $3602 \mathrm{mg}$ with a progeny of 466 parasitoids/pupa (Barbosa et al., 2015) with parasitoid offspring consuming $7.73 \mathrm{mg}$ weight of host pupae. Therefore $O$. vesulia pupae produced 4.5 times more parasitoid offspring per host tissue weight compared to E. ello, demonstrating that the progeny of this parasitoid varies with the host species and biomass (Favero et al., 2013). This is similar to that reported for Trichospilus diatraeae Cherian and Margabandhu (Hymenoptera: Eulophidae) and T. howardi on pupae of Helicoverpa armigera Hubner (Lepidoptera: Noctuidae), with $373 \mathrm{mg}$ generating 669.3 T. howardi parasitoids and 816.11 T. diatraeae parasitoids, each consuming $0.56 \mathrm{mg}$ and $0.46 \mathrm{mg}$ of the host per individual produced, respectively. Tetrastichus howardi offspring consumed around 1.2 times more host mass than $T$. diatraeae, with a difference of 146.8 parasitoids produced from the host $H$. armigera. This variation in the number of individuals per host pupae for these endoparasitoids is probably due to their size, with T. howardi larger than T. diatraeae (Oliveira et al.,
2016). The parasitoid T. diatraeae produced 868 parasitoids per pupae of the host Spodoptera cosmioides Walker (Lepidoptera: Noctuidae) (Zaché et al., 2012). The sex ratio of $T$. howardi, with a predominance of females, may increase the efficiency of this parasitoid in the biological control, since they are responsible for parasitism and host control (Cañete and Foerster 2003; Zacarin et al., 2004).

The species $O$. vesulia has potential to be used as an alternative host to mass rearing $T$. howardi, with a production of $321 \pm 28.7$ parasitoids/host pupa. The parasitism of $O$. vesulia caterpillars and pupae by $T$. howardi shows the potential of this natural enemy for the integrated management of this defoliator pest in eucalyptus plantations.

\section{Acknowledgements}

We thank Dr. Valmir Antonio Costa, of the "Instituto Biológico", for the identification of T. howardi. We thank the Brazilian institutions "Conselho Nacional de Desenvolvimento Científico e Tecnológico (CNPq), Coordenação de Aperfeiçoamento de Pessoal de Nível Superior (CAPES- Finance Code 001), Fundação de Amparo à Pesquisa do Estado de Minas Gerais (FAPEMIG)" and "Programa Cooperativo sobre Proteção Florestal/PROTEF do Instituto de Pesquisas e Estudos Florestais/IPEF" for financial support. David Michael Miller, a professional editor and proofreader and native English speaking, who has reviewed and edited this article for grammar, punctuation, spelling, structure, word choice, and readability.

\section{References}

ANDRADE, G.S., SERRAO, J.E., ZANUNCIO, J.C., ZANUNCIO, T.V., LEITE, G.L.D. and POLANCZYK, R.A., 2010. Immunity of an alternative host can be overcome by higher densities of its parasitoids Palmistichus elaeisis and Trichospilus diatraeae. PLoS One, vol. 5, no. 10, pp. e13231.

ASGARI, S. and RIVERS, D.B., 2011. Venom proteins from endoparasitoid wasps and their role in host-parasite interactions. Annual Review of Entomology, vol. 56, no. 1, pp. 313-335. http:// dx.doi.org/10.1146/annurev-ento-120709-144849. PMid:20822448.

BAITHA, A.R.U.N., JALALI, S.K., RABINDRA, R.J., VENKATESAN, T.R.A.O.N.S and RAO, N.S., 2004. Parasitising efficiency of the pupal parasitoid, Tetrastichus howardi (Olliff) (Hymenoptera: Eulophidae) on Chilo partellus (Swinhoe) at different exposure periods. Journal of Biological Control, vol. 18 , no. 1 , pp. $65-68$.

BARBOSA, R.H., KASSAB, S.O., PEREIRA, F.F., ROSSONI, C., COSTA, D.P. and BERNDT, M.A., 2015. Parasitism and biological aspects of Tetrastichus howardi (Hymenoptera: Eulophidae) on Erinnyis ello (Lepidoptera: Sphingidae) pupae. Ciência Rural, vol. 45 , no. 2 , pp. 185-188. http://dx.doi.org/10.1590/0103$8478 \mathrm{cr} 20130896$.

BARBOSA, R.H., ZANUNCIO, J.C., PEREIRA, F.F., KASSAB, S.O. and ROSSONI, C., 2016. Foraging activity of Palmistichus elaeisis (Hymenoptera: Eulophidae) at various densities on pupae of the eucalyptus defoliator Thyrinteina arnobia (Lepidoptera: Geometridae). The Florida Entomologist, vol. 99, no. 4, pp. 686691. http://dx.doi.org/10.1653/024.099.0417. 
CAMPOS, W.G. and CURE, J.R., 1993. Lagartas, seus danos e parasitoides associados em reflorestamentos de Eucalyptus cloeziana no Vale do Rio Doce (MG). Revista Brasileira de Entomologia, vol. 37, pp. 1-13.

CAÑETE, C.L. and FOERSTER, L.A., 2003. Incidência natural e biologia de Trichogramma atopovirilia Oatman \& Platner, 1983 (Hymenoptera, Trichogrammatidae) em ovos de Anticarsia gemmatalis Hübner, 1818 (Lepidoptera, Noctuidae). Revista Brasileira de Entomologia, vol. 47, no. 2, pp. 201-204.

COLINET, D., MATHÉ-HUBERT, H., ALLEMAND, R., GATTI, J.-L. and POIRIÉ, M., 2013. Variability of venom components in immune suppressive parasitoid wasps: from a phylogenetic to a population approach. Journal of Insect Physiology, vol. 59, no. 2, pp. 205-212. http://dx.doi.org/10.1016/j.jinsphys.2012.10.013. PMid:23103980.

CRUZ, I., REDOAN, A.C., SILVA, R.B.D., FIGUEIREDO, M.D.L.C. and PENTEADO-DIAS, A.M., 2011. New record of Tetrastichus howardi (Olliff) as a parasitoid of Diatraea saccharalis (Fabr.) on maize. Scientia Agrícola, vol. 68, no. 2, pp. 252-254. http://dx.doi.org/10.1590/S0103-90162011000200017.

ESPINDOLA, C.B. and GONÇALVES, L., 2000. Biology of Oxydia vesulia (CRAMER, 1779) (LEPIDOPTERA: GEOMETRIDAE). Floresta e Ambiente, vol. 7, no. 1, pp. 80-87.

FAVERO, K., PEREIRA, F.F., KASSAB, S.O., OLIVEIRA, H.N.D., COSTA, D.P. and ZANUNCIO, J.C., 2013. Biological characteristics of Trichospilus diatraeae (Hymenoptera: Eulophidae) are influenced by the number of females exposed per pupa of Tenebrio molitor (Coleoptera: Tenebrionidae). The Florida Entomologist, vol. 96, no. 2, pp. 583-589. http://dx.doi. org/10.1653/024.096.0224.

LA SALLE, J. and POLASZEK, A., 2007. Afrotropical species of the Tetrastichus howardi species group (Hymenoptera: eulophidae). African Entomology, vol. 15, no. 1, pp. 45-56. http://dx.doi. org/10.4001/1021-3589-15.1.45.

MOORE, S.D. and KFIR, R., 1995. Aspects of the biology of the parasitoid, Tetrastichus howardi (Olliff) (Hymenoptera: eulophidae). Journal of African Zoology, vol. 109, no. 5/6, pp. 455-466.

OLIVEIRA, H.N., PRATISSOLI, D., ZANUNCIO, J.C. and SERRÃO, J.E., 2003. Influence of the age of Oxydia vesulia eggs on parasitism by Trichogramma maxacalii. Pesquisa Agropecuária Brasileira, vol. 38, no. 4, pp. 551-554. http://dx.doi.org/10.1590/ S0100-204X2003000400015.

OLIVEIRA, H.N., SIMONATO, J., GLAESER, D.F. and PEREIRA, F.F., 2016. Parasitism of Helicoverpa armigera pupae (Lepidoptera: Noctuidae) by Tetrastichus howardi and Trichospilus diatraeae (Hymenoptera: Eulophidae). Semina: Ciências Agrárias, vol. 37, no. 1, pp. 111-115. http://dx.doi. org/10.5433/1679-0359.2016v37n1p111.

PEREIRA, F.F., KASSAB, S.O., CALADO, V.R.F., VARGAS, E.L., OLIVEIRA, H.N. and ZANUNCIO, J.C., 2015. Parasitism and emergence of Tetrastichus howardi (Hymenoptera: Eulophidae) on Diatraea saccharalis (Lepidoptera: Crambidae) larvae, pupae and adults. The Florida Entomologist, vol. 98, no. 1, pp. 377-380. http://dx.doi.org/10.1653/024.098.0164.

RIBEIRO, R.C., PIKART, T.G., FOUAD, H.A., PARREIRA, M.C., ZANUNCIO, J.C., SOARES, M.A. and CASTRO, V.R., 2019. Trichospilus diatraeae (Hymenoptera: Eulophidae): development and reproduction in Lepidoptera palm oil pests. Brazilian Journal of Biology = Revista Brasileira de Biologia, vol. 79, no. 3, pp. 377-382. http://dx.doi.org/10.1590/15196984.173211. PMid:30484477.

SANTOS, G.P., ZANUNCIO, T.V., VINHA, E. and ZANUNCIO, J.C., 2002. Influência de faixas de vegetação nativa em povoamentos de Eucalyptus cloeziana sobre população de Oxydia vesulia (Lepidoptera: geometridae). Revista Árvore, vol. 26, no. 4, pp. 499-504. http://dx.doi.org/10.1590/S0100-67622002000400013.

VARGAS, E.L., PEREIRA, F.F., TAVARES, M.T. and PASTORI, P.L., 2011. Record of Tetrastichus howardi (Hymenoptera: Eulophidae) parasitizing Diatraea sp. (Lepidoptera: Crambidae) in sugarcane crop in Brazil. Entomotrópica, vol. 26, no. 3, pp. 143-146.

ZACARIN, G.G., GOBBI, N. and CHAUD-NETTO, J., 2004. Preferência de Apanteles galleriae Wilkinson (Hymenoptera: Braconidae) por Galleria mellonella (L.) ou Achroia grisella (Fabricius) (Lepidoptera: Pyralidae). Neotropical Entomology, vol. 33, no. 1, pp. 65-70.

ZACHÉ, B., WILCKEN, C.F., ZACHÉ, R.R.C. and SOUZA, N.M., 2012. New occurrence of Trichospilus diatraeae Cherian \& Margabandhu, 1942 (Hymenoptera: Eulophidae) as a parasitoid of Spodoptera cosmioides Walker, 1858 (Lepidoptera: Noctuidae) in Brazil. Biota Neotropica, vol. 12, no. 1, pp. 319-322.

ZANUNCIO, J.C., CRUZ, A.P., RAMALHO, F.S., SERRÃO, J.E., WILCKEN, C.F., SILVA, W.M., JÚNIOR, V.C.S. and FERREIRA-FILHO, P.J., 2018. Environmental determinants affecting the occurrence of defoliator caterpillars on Eucalyptus (Myrtaceae) plantations in the Brazilian Amazonian region. The Florida Entomologist, vol. 101, no. 3, pp. 480-486. http://dx.doi. org/10.1653/024.101.0306.

ZANUNCIO, J.C., GUEDES, R.N.C., CRUZ, A.P.D. and MOREIRA, A.M., 1992. Eficiência de Bacillus thuringieneis e de deltametrina, em aplicação aérea, para o controle de Thyrinteina arnobia Stoll, 1782 (Lepidoptera: Geometridae) em eucaliptal no Pará. Acta Amazonica, vol. 22, no. 4, pp. 485-492. http://dx.doi. org/10.1590/1809-43921992224492.

ZANUNCIO, J.C., NASCIMENTO, E.C., GARCIA, J.F. and ZANUNCIO, T.V., 1994. Major lepidopterous defoliators of eucalypt in southeast Brazil. Forest Ecology and Management, vol. 65, no. 1, pp. 53-63. http://dx.doi.org/10.1016/0378-1127(94)90257-7.

ZANUNCIO, J.C., SANTANA, D.L.Q., DO NASCIMENTO, E.C., SANTOS, G.P., ALVES, J.B., SARTÓRIO, R.C. and ZANUNCIO, T.V., 1993. Manual de pragas em florestas. Lepidoptera desfolhadores de eucalipto: biologia, ecologia e controle. Viçosa: Folha de Viçosa, pp. 12-66. 